\title{
LIMING AND ELECTROCHEMICAL ATTRIBUTES OF AN OXISOL UNDER NO TILLAGE
}

\author{
Luís Reynaldo Ferracciú Alleoni ${ }^{1,3 *}$; Fernando César Bachiega Zambrosi ${ }^{1,3}$; Silvino Guimarães \\ Moreira $^{1,4}$; Luís Ignácio Prochnow ${ }^{1,3}$; Volnei Pauletti ${ }^{2}$ \\ ${ }^{1}$ Depto. de Solos e Nutrição de Plantas - USP/ESALQ, C.P. 09 - CEP: 13418-900 - Piracicaba, SP. \\ ${ }^{2}$ Fundação $A B C$ - BR 151, km 155.5, C.P.1003 - CEP: 84166-900 - Castro, PR. \\ ${ }^{3} \mathrm{CNPq}$ Fellow. \\ ${ }^{4}$ FAPESP Fellow. \\ *Corresponding author <Irfalleo@esalq.usp.br>
}

\begin{abstract}
No tillage areas are increasing in Brazil especially due to a general improvement in water and nutrient availability to plants. Few results have reported the effect of liming on soil electrochemical attributes in areas under the no tillage system. This study was conducted to evaluate the effect of liming (at the soil surface and incorporated to $0.2 \mathrm{~m}$ ) on soil pH, point of zero salt effect (PZSE), electric potential, soil organic matter (SOM), and yield of soybean and corn, cultivated on an Typic Hapludox, submitted 12 years to no tillage. Rates of lime of $1 / 3,2 / 3$ and the total amount calculated for soil to reach a base saturation of $70 \%\left(2.5\right.$ ton ha $\left.{ }^{-1}\right)$ were applied on soil surface. The full rate was also applied and incorporated to the $0.2 \mathrm{~m}$ depth. The effect of liming on PZSE was low due, most likely, to the low lime rates used in the experiment. SOM contents decreased as rates of applied lime increased, with the highest variation occurring between the control and the full rate of lime when incorporated. No clear effect of the lower values of SOM was observed in the PZSE values. The lack of interaction among lime rates and soil depth contributed for this situation, once the effect of SOM was diluted when considering the values of PZSE as the average for the soil layers $(0-0.1 ; 0.1-0.2$ and $0.2-0.3 \mathrm{~m})$. There was no variation in the soil electric potential and in the yield of soybean and corn as a function of lime rates. Key words: PSSE, organic matter, electric potential
\end{abstract}

\section{CALAGEM E ATRIBUTOS ELETROQUÍMICOS DE UM LATOSSOLO SOB SISTEMA DE SEMEADURA DIRETA}

\begin{abstract}
RESUMO: O aumento das áreas cultivadas no Brasil sob sistema de semeadura direta (SSD) vem ocorrendo principalmente devido às melhorias na disponibilidade de água e de nutrientes às plantas. Entretanto, poucos estudos têm sido realizados sobre o efeito da calagem nos atributos eletroquímicos dos solos cultivados sob SSD. O objetivo desse estudo foi avaliar o efeito da calagem (na superfície do solo e incorporada a 0,2 m) no pH do solo, no ponto de efeito salino nulo (PESN), no potencial elétrico, no teor de matéria orgânica do solo (MOS) e na produtividade de soja e milho cultivados em um Latossolo Vermelho com 12 anos sob SSD. As doses de calcário aplicadas na superfície representaram 1/3, 2/3 e o total da quantidade calculada para elevar a saturação por bases a $70 \%\left(2500 \mathrm{~kg} \mathrm{ha}^{-1}\right)$. Avaliou-se um tratamento adicional, constituído pela maior dose, incorporada na camada de 0 a 0,2 m. Houve efeito pouco pronunciado da calagem nos valores de PESN, provavelmente devido às pequenas doses de calcário utilizadas. O conteúdo de MOS decresceu com o aumento das doses de calcário, sendo que a maior variação ocorreu entre a testemunha e a dose incorporada. Não ocorreu efeito claro desse abaixamento da MOS nos valores do PESN. A falta de interação entre as doses de calcário e as profundidades de coleta do solo contribuiu para esta situação, porque o efeito da MOS foi diluído, uma vez que os valores de PESN eram médios das profundidades $(0-0,1 ; 0,1-0,2$ and 0,2-0,3 m). O potencial elétrico e as produtividades de soja e milho não variaram com as doses de calcário. Palavras-chave: PESN, matéria orgânica, potencial elétrico
\end{abstract}

\section{INTRODUCTION}

Areas under cultivation by the no tillage system are increasing in Brazil, especially due to a general improvement in soil water and nutrient availability to plants (Hernani et al., 1999). In the year 2000 about 13.5 millions of hectares were already under this cultivation system in Brazil (Derpsch, 2002).

In the no tillage system the soil should not be disturbed. As a consequence, plowing is not used, and the effectiveness of lime applied on the soil surface was questionable for many years. Lately, some researchers have shown that even when applied on the surface, lime was effective under no tillage (Sá, 1995; Potker \& Ben, 1998; Caires et al., 1999). Authors claimed increases in the soil surface profile of organic matter (Maria \& Castro, 1993; Paiva et al., 1997); phosphorus (Kitur et al., 1994; Selles et al., 1997); calcium, magnesium and soil pH (Caires et al., 1999; Moreira et al., 2001), due to lime applied to soil surface under no tillage. Few results have reported the effect of liming on soil electrochemical properties, most specially the zero point of charge (ZPC), in areas under the no tillage system. 
As a consequence of soil organic matter presenting low values of ZPC (Alleoni \& Camargo, 1994), the average value for this electrochemical property should be low in the surface soil profile. In Oxisols, the most common soil type in Brazil, subsurface soil horizons generally present higher ZPC values due to the lower contents of organic matter (Dynia \& Camargo, 1998) or to the presence of iron and aluminum hydroxides, which present high values of ZPC (Ranst et al., 1998). As proposed by Alleoni \& Camargo (1994), the point of zero salt effect (PZSE), which is obtained by potenciometric titration, adequately estimates the ZPC.

Little information exists regarding the effect of liming on soil PZSE. Data available are not consistent. Mora et al. (1999) reported a reduction in PZSE values due to the application of lime to an Andisol from Chile, whereas Albuquerque et al. (2000) and Cambri (2000) reported opposite results.

This study was carried out to further evaluate the effect of lime application (on the soil surface and incorporated to $0.2 \mathrm{~m}$ ) on soil $\mathrm{pH}, \mathrm{PZSE}$, electric potential, soil organic matter, calcium and magnesium contents, and yield of soybean and corn cultivated in an Oxisol cultivated twelve years under no tillage.

\section{MATERIAL AND METHODS}

The field experiment was conducted under a Typic Hapludox in Tibagi, PR, Brazil $\left(24^{\circ} 28^{\prime} \mathrm{S}, 50^{\circ} 27^{\prime} \mathrm{W}\right)$. In the winter of 1989 , before adopting the no tillage system, the soil was plowed to the $0.2 \mathrm{~m}$ depth using a moldboard plow. Dolomitic limestone $(\mathrm{CaO}=27 \%, \mathrm{MgO}$ $=20 \%$, with percente effective calcium carbonate of $84 \%$ ) was incorporated to $0.2 \mathrm{~m}$ at a rate to reach $70 \%$ of base saturation. Before installing the experiment, other two lime applications of 2 ton ha ${ }^{-1}$ each were used, according to Sá (1995). At the time the experiment was initiated (May of 1998), the area had not received lime for three years. The soil chemical analysis of the first $0.2 \mathrm{~m}$ layer at this time revealed the following results: $\mathrm{pH}$ in $\mathrm{CaCl}_{2}$ $0.01 \mathrm{~mol} \mathrm{~L}^{-1}=5.1$; organic matter $=47 \mathrm{~g} \mathrm{dm}^{-3} ; \mathrm{P}$ extracted by the ion exchange resin $=44 \mathrm{mg} \mathrm{dm}^{-3} ; \mathrm{K}=2,6 ; \mathrm{Ca}=$ 34; $\mathrm{Mg}=21 ; \mathrm{Al}=0 ; \mathrm{H}+\mathrm{Al}=52 ; \mathrm{CEC}_{\mathrm{pH7}}=110 \mathrm{mmol}_{\mathrm{c}}$ $\mathrm{dm}^{-3}$ and base saturation $=53 \%$. The analytical procedures followed Raij et al. (1987).

The experimental design consisted of completely randomized blocks with four replicates and experimental units of $8.3 \times 12.5$ meters. Rates of lime of $1 / 3,2 / 3$ and the total amount calculated to reach base saturation of $70 \%$ (2.5 ton) were hand applied on soil surface. The full rate was also incorporated to $0.2 \mathrm{~m}$ with a disc plow. After liming, white oat was mechanically seeded at the rate of $70 \mathrm{~kg}$ of seeds per ha, $0.15 \mathrm{~m}$ between lines, using no fertilization.

Seeds of the EMBRAPA 59 soybean were planted in October 1998, $0.45 \mathrm{~m}$ between lines, 16 seeds per meter, with a fertilization of $200 \mathrm{~kg} \mathrm{ha}^{-1}$ of the formula
0-20-20. The seeds were inoculated with a solution of sodium molibdate containing Bradyrhizobium and treated with thiran. After harvesting the soybean, in March 1999, black oat was planted again. In October 1999, corn XL8392 seeds were planted, $0.8 \mathrm{~m}$ between lines and 5 seeds per meter, adding $300 \mathrm{~kg} \mathrm{ha}^{-1}$ of the 10-20-10 + $1 \%$ Zn formula. In May 2000 black oat was again planted and in November 2000, soybean BRS 49 was seeded at the same rate and conditions used for the first soybean crop in 1998.

Soil samples were taken at the end of July 1999 from $0-0.1 ; 0.1-0.2$ and $0.2-0.3 \mathrm{~m}$. Ten soil samples were collected in each experimental unit and mixed, resulting in one composit sample. The accumulated rainfall between liming and soil sampling reached $2100 \mathrm{~mm}$. Soil samples were dried at $40^{\circ} \mathrm{C}$, crushed and sieved through $2 \mathrm{~mm}$ size, and submitted to the determinations of $\mathrm{pH}$, organic matter, $\mathrm{K}, \mathrm{Ca}$ and $\mathrm{Mg}$ contents.

The PZSE was obtained by titration (Alleoni \& Camargo, 1994). To samples of $4.0 \mathrm{~g}$ received $20 \mathrm{~mL}$ of a $\mathrm{KCl}$ solution $\left(0.1 ; 0.01 ; 0.001 \mathrm{~mol} \mathrm{~L}^{-1}\right)$ combined with $\mathrm{HCl}\left(0.002 ; 0.004 ; 0.008 .0 .012 ; 0.016 \mathrm{~mol} \mathrm{~L}^{-1}\right)$ or with $\mathrm{NaOH}\left(0.002\right.$ and $\left.0.004 \mathrm{~mol} \mathrm{~L}^{-1}\right)$. The PZSE was determined in three replicates. The $\mathrm{pH}$ values were measured after $24 \mathrm{~h}$ of solution equilibrium. The electric potential was calculated using the simplified Nernst equation: $y=59.1(P Z S E-p H)$, in $\mathrm{mV}$.

Soybean was harvested in March 1999 and April 2001, and corn was harvested in March 2000. For soybean the four central lines, $4 \mathrm{~m}$ long, were used for yield valuation, whereas for corn the 4 central lines, $2 \mathrm{~m}$ long, were used. Grain was sieved, weighted and submitted to the determination of moisture. For yield calculation, an average of $13 \%$ of grain moisture was considered.

The results were subjected to analysis of variance ( $F$ test), and means compared by the Tukey test at $5 \%$. Mean comparison was used, instead of polynomial regression, due to the fact that the lime application was not uniform for all treatments.

\section{RESULTS AND DISCUSSION}

The interaction between soil sampling depth and rates of lime applied was not significant. As a consequence, the effects of rate and depth will be discussed separately. The effect of liming on the PZSE was low (Figure 1). The shape for the curves and the values of PZSE were close, with a maximum difference in PZSE of 0.5 unit. PZSE values between 3 and 4 are common in weathered soil layers, mostly due, especially, to the effect of soil organic matter (Alleoni \& Camargo, 1994). Since all soil samples showed PZSE values lower than $\mathrm{pH}$, a negative charge balance should be expected. The low effect of liming on the PZSE was due, most likely, to the low lime rates used in the experiment, as compared to the rates used by other authors. 


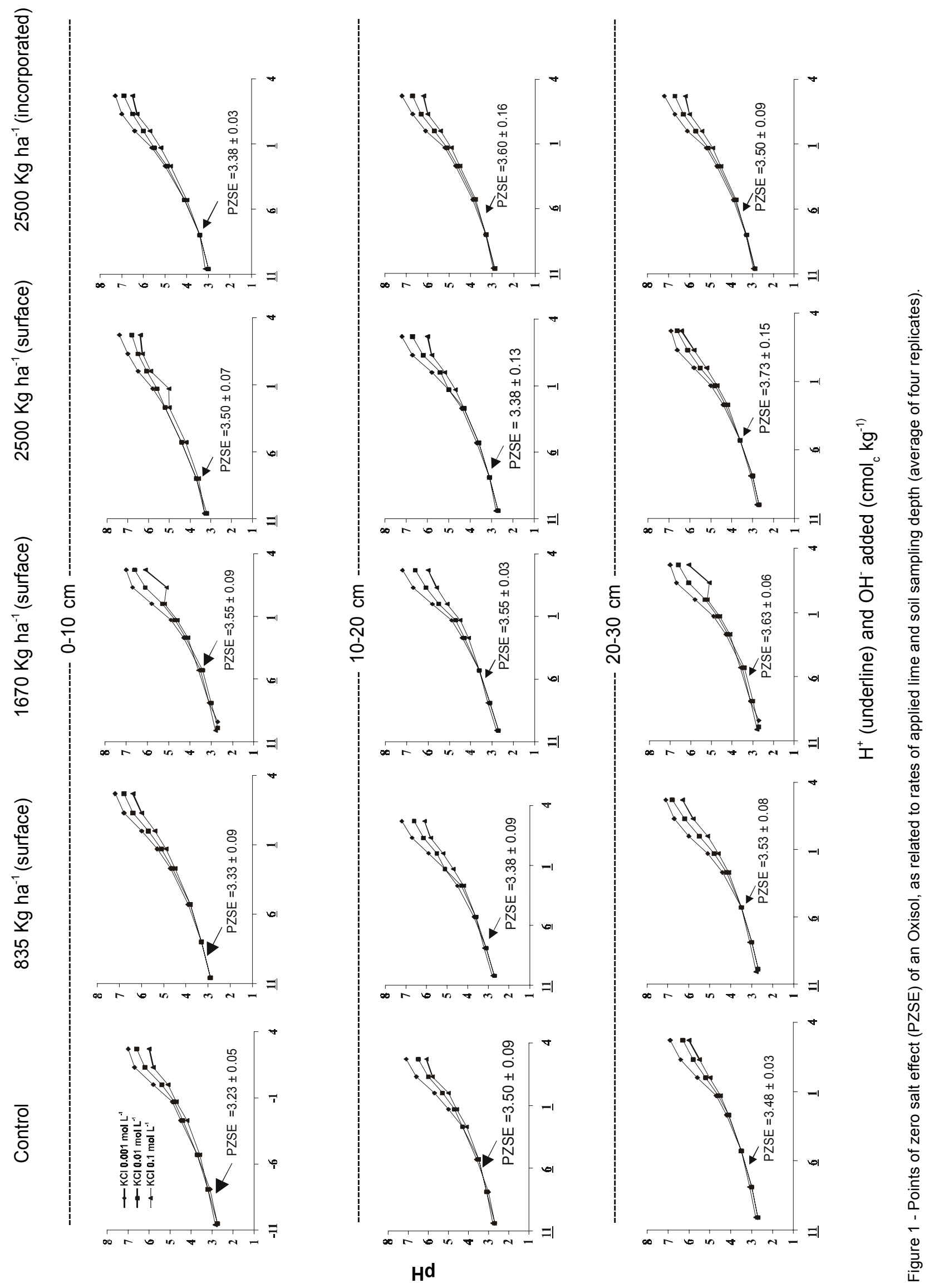


PZSE increments as a function of soil liming is generally related to increases in the concentrations of $\mathrm{Ca}$ and $\mathrm{Mg}$, ions which can specifically be adsorbed (Oliveira et al., 1999; Albuquerque et al., 2000) by Fe and $\mathrm{Al}$ hydroxides and by the organic matter functional groups (Charlet, 1986). As a consequence of this adsorption, positive charges are incorporated to the edge of soil colloids, decreasing the net negative charge, which finally results in an increase of the PZSE. The inner-sphere complexes formed by the specific adsorption are more important for $\mathrm{Ca}$ than for $\mathrm{Mg}$, and the stability constants of formation for the $\mathrm{Ca}$ complex are higher than those for the Mg complex (Charlet, 1986). In this study, the rates of applied lime were not sufficient to significantly modify the concentrations of $\mathrm{Ca}$ and $\mathrm{Mg}$ in the soil (Table 1), and this should be the main reason for low deviations in the values of PZSE among treatments.

As already stated, rates of lime used in this experiment were low ( 0.8 to 2.5 tons per hectare), they are, however, in accordance to those normally applied on soils under no tillage, which are limited with 1.5 to 2.5 tons per hectare, for sandy and clayey soils, respectively (Sá, 1995). To obtain larger variations in the PZSE, rates would have to be higher than those used in the experiment, as experienced by Albuquerque et al. (2000) and Cambri (2000). Cambri (2000) noted that six months after lime application soil samples taken from the 0-0.05 $\mathrm{m}$ layer of an Oxisol, located in Rondonópolis, MT, Brazil and cultivated for six years under no tillage, had PZSE values increased from 3.2 for the control to 5.7 for an application of 7.8 ton ha ${ }^{-1}$ of lime. Albuquerque et al. (2000) obtained variation of 3.8 to 4.3 in the PZSE values five years after lime incorporation to $0.17 \mathrm{~m}$, when applying 4.5 and 18 tons per hectare, respectively, on an Oxisol.

Results for soil organic matter presented a clear trend for a decrease as rates of lime applied increased, with the higher variation occurring between the control and when the full rate of lime was incorporated to $0.2 \mathrm{~m}$ in the soil profile $\left(4.9 \mathrm{~g} \mathrm{~kg}^{-1}\right)$. Organic matter contents are inversely related to PZSE (Siqueira et al., 1990; Benites \& Mendonça, 2000). OM covers the $\mathrm{Fe}$ and $\mathrm{Al}$ hydroxides, which present high values of PZSE, and are positively charged for most common values of soil $\mathrm{pH}$. Also, after liming, negative charges are formed in the organic matter by the dissociation of carboxyl groups, which promote a decrease in PZSE (Canellas et al., 1999). The adsorption of organic acids by clay minerals can promote an increment of negative charges in the soil system, and consequently, decrease PZSE (Oades, 1984). In this study, no clear effect of lower values of soil organic matter was observed on PZSE. The lack of interaction among lime rates and soil depth certainly contributed for this situation, once the effect of soil organic matter was diluted when considering the values of PZSE as the average for all three soil layers.
There was no variation in soil electric potential as a function of liming rates (Table 1). The electric potential is the difference between PZSE and $\mathrm{pH}$ in water (Figure 1, Tables 1 and 2), and variations in these values were low. Once again, the lack of interaction between rates of liming and soil depth should have contributed for no variation in soil electric potential. Albuquerque et al. (2000) obtained an increase from -73 to $-159 \mathrm{mV}$ by applying 18 ton ha ${ }^{-1}$ of lime. According to these authors, the lime increased the negative electric potential of the soil as a result of hydroxyl adsorption in the positively charged surface of oxides and hydroxides (Cornell \& Schwertmann, 1996) and of broken edges of kaolinite (McBride, 1989). The dissociation of organic matter functional groups, the carboxyl being the most important (Schnitzer, 1986), also contributes to an increase of negative charges.

Grain yields of soybean and corn were not influenced by lime application (Table 3 ). Similar results were obtained by Caires et al. (1998) and Caires et al. (1999) in acid soils located in the state of Paraná, Brazil. The results suggest that the base saturation of $53 \%$ on the top $0.2 \mathrm{~m}$ soil layer should be enough to achieve maximum yield. Sá (1995) suggested that liming is not necessary in soils under no tillage when the base saturation is above $45 \%$, because liming such soils could lead to micronutrient deficiencies, and consequently, decrease grain yield. In the present study, close attention

Table 1 - Values for $\mathrm{pH}$, soil organic matter (SOM), Ca, $\mathrm{Mg}$, and the electric potential $\left(\psi_{0}\right)$ in an Oxisol as related to rates of applied lime (average of 12 replicates).

\begin{tabular}{|c|c|c|c|c|c|}
\hline Rates & $\mathrm{pH} \quad\left(\mathrm{CaCl}_{2}\right)$ & $\mathrm{SOM}$ & $\mathrm{C} \mathrm{a}$ & $\mathrm{Mg}$ & $\Psi_{0}$ \\
\hline & & $g \mathrm{dm}^{-3}$ & $-\mathrm{m} \mathrm{mol}$ & $l_{c} \mathrm{dm}^{-3}-$ & $\mathrm{m} \mathrm{V}$ \\
\hline 0 & $5.6 \mathrm{~b}^{R)}$ & $47.4 \mathrm{a}$ & $33.4 \mathrm{e}$ & $202 d$ & $-129 a$ \\
\hline 833 surf. $^{(1)}$ & $5.8 \mathrm{ab}$ & $45.4 \mathrm{~b}$ & $33.9 \mathrm{~d}$ & $201 \mathrm{e}$ & $-127 a$ \\
\hline 1.667 surf. & $5.8 \mathrm{ab}$ & $45.0 \mathrm{~d}$ & $39.8 \mathrm{c}$ & $23.1 \mathrm{c}$ & $-139 a$ \\
\hline 2.500 surf. & $5.8 \mathrm{ab}$ & $45.1 \mathrm{C}$ & $40.8 \mathrm{~b}$ & $24.6 \mathrm{~b}$ & $-135 a$ \\
\hline 2.500 inc. & $5.9 \mathrm{a}$ & $42.5 \mathrm{e}$ & $443 a$ & $25.7 \mathrm{a}$ & $-141 a$ \\
\hline$C . V \quad(\%)$ & 3.8 & 5.8 & 17.5 & 16.8 & 9.5 \\
\hline
\end{tabular}

${ }^{(1)}$ surf. = applied on soil surface; inc. = incorporated to $0.2 \mathrm{~m}$; ${ }^{(2)} \mathrm{low}$ case letters compare the effect of rates of applied lime on soil attributes, by the Tukey test at $5 \%$.

Table 2 - Values for the point of zero salt effect (PZSE), $\mathrm{pH}$, soil organic matter (SOM), $\mathrm{Ca}, \mathrm{Mg}$, and the electric potential $\left(\psi_{0}\right)$ in an Oxisol as related to soil sampling depth (average of 20 replicates).

\begin{tabular}{|c|c|c|c|c|c|c|}
\hline Dep & $\mathrm{PZSE} \quad \mathrm{pH}$ & $\left(\mathrm{CaC}_{2}\right)$ & $\mathrm{SOM}$ & $\mathrm{C} \mathrm{a}$ & $\mathrm{M} \mathrm{g}$ & $\Psi_{0}$ \\
\hline $\mathrm{m}$ & & & $g \mathrm{dm}^{-3}$ & $\mathrm{~m} \mathrm{~m}$ & $m^{-3}$ & $\mathrm{~m} \mathrm{~V}$ \\
\hline $0-0$ & $3.4 \mathrm{~b}^{(1)}$ & $5.9 \mathrm{a}$ & $50.9 \mathrm{a}$ & 8.1 & $9.0 \mathrm{a}$ & -150 \\
\hline $0.1-$ & $3.5 \mathrm{ab}$ & $5.7 \mathrm{~b}$ & $43.8 \mathrm{~b}$ & 36.1 & $19.8 \mathrm{~b}$ & $-129 \mathrm{~b}$ \\
\hline $2-0.3$ & 6 c & $5.7 \mathrm{~b}$ & $40.6 \mathrm{C}$ & $313 \mathrm{c}$ & $19.4 \mathrm{C}$ & -123 \\
\hline
\end{tabular}

(1) low case letters compare the effect of soil sampling depth on soil attributes, by the Tukey test at $5 \%$. 
Table 3 - Soybean and corn yields as related to the rate of applied lime (average of four replicates).

\begin{tabular}{lccc}
\hline Rates & $\begin{array}{c}\text { Soybean } \\
(98 / 99)\end{array}$ & Com (99/00) & $\begin{array}{c}\text { Soybean } \\
(00 / 01)^{\beta)}\end{array}$ \\
\hline 0 & $3724 \mathrm{a}^{\mathrm{R})}$ & $8697 \mathrm{a}$ & $3555 \mathrm{a}$ \\
833 surf. $^{(1)}$ & $3515 \mathrm{a}$ & $8602 \mathrm{a}$ & $3654 \mathrm{a}$ \\
1.667 surf. & $3306 \mathrm{a}$ & $9223 \mathrm{a}$ & $3447 \mathrm{a}$ \\
2.500 surf. & $3452 \mathrm{a}$ & $9286 \mathrm{a}$ & $3629 \mathrm{a}$ \\
2.500 inc. & $3863 \mathrm{a}$ & $9300 \mathrm{a}$ & $3525 \mathrm{a}$ \\
\hline $\mathrm{C} . \mathrm{V} \mathrm{( \% )}$ & 8.2 & 9.2 & 4.8 \\
\hline
\end{tabular}

${ }^{(1)}$ surf. = applied on soil surface; inc. = incorporated to $0.2 \mathrm{~m}$; ${ }^{(2)} \mathrm{low}$ case letters compare the effect of rates of applied lime on soil attributes, by the Tukey test at $5 \% .{ }^{(3)}$ yield of soybean in $00 / 01$ was obtained from the $A B C$ foundation internal report.

was given to micronutrient deficiency during crop growth, and such symptoms were not identified, even on the experimental units which received the highest rates of lime. The low effect of liming on PZSE and soil electric potential was in accordance with the absence of differences in yield as previously discussed.

\section{REFERENCES}

ALLEONI, L.R.F.; CAMARGO, O.A. Ponto de efeito salino nulo de latossolos ácricos. Revista Brasileira de Ciência do Solo, v.18, p.175-180, 1994.

ALBUQUERQUE, J.A.; BAYER, C.; ERNANI, P.R.; FONTANA, E.C. Propriedades físicas e eletroquímicas de um latossolo bruno afetadas pela calagem. Revista Brasileira de Ciência do Solo, v.24, p.295-300, 2000.

BENITES, V.M.; MENDONÇA, E.S. Propriedades eletroquímicas de um solo eletropositivo influenciadas pela adição de diferentes fontes de matéria orgânica Revista Brasileira de Ciência do Solo, v.24, p.191-198, 2000.

CAIRES, E.F.; MADRUGA, E.F.; CHUEIRI, W.A.; FIGUEIREDO, A. Alterações das características químicas do solo e resposta da soja ao calcário e gesso aplicados na superfície em sistema de cultivo sem preparo do solo. Revista Brasileira de Ciência do Solo, v.22, p.27-34, 1998.

CAIRES, E.F.; FONSECA, A.F.; MENDES, J.; CHUEIRI, W.A.; MADRUGA, E.F. Produção de milho, trigo e soja em função das alterações das características químicas do solo pela aplicação de calcário e gesso na superfície, em sistema de plantio direto. Revista Brasileira de Ciência do Solo, v.23, p.315-327, 1999.

CAMBRI, M.A. Atributos químicos e produção de soja em um latossolo de cerrado sob semeadura direta em função da calagem. Piracicaba, 2000. 104p. Dissertação (Mestrado) - Escola Superior de Agricultura "Luiz de Queiroz", Universidade de São Paulo.

CANELLAS, L.P.; SANTOS, G.A.; AMARAL SOBRINHO, N.M.B. Reações da matéria orgânica. In: SANTOS, G.A.; CAMARGO, F.A.O. (Ed.) Fundamentos da matéria orgânica do solo: ecossistemas tropicais e subtropicais. Porto Alegre: Genesis, 1999. cap.3, p.69-90.

CHARLET, L. Adsorption of some macronutrient íons on an Oxisol. An Aplication of the triple layer model. Riverside, 1986. 148p. Thesis (Doctor) - University of California.
CORNELL, R.M.; SCHWERTMANN, U. The iron oxides: structure, properties, reactions, occurrence and uses. Weinheim: VCH, 1996. 573p.

DERPSCH, R. Expansão mundial do plantio direto, ano 2000. Revista Plantio Direto Virtual. www. plantiodireto.com.br. (fev. 2002)

DYNIA, J.F.; CAMARGO, O.A. Effects of liming, green manuring, and phosphate addition on electrochemical attributes of an Oxisol from Central Brazil. Communications in Soil Science and Plant Analysis, v.29, p.755762, 1998.

HERNANI, L.C.; KURIHARA, C.H.; SILVA, W.M. Sistemas de manejo de solo e perdas de nutrientes e matéria orgânica por erosão. Revista Brasileira de Ciência do Solo, v.23, p.145-154, 1999.

KITUR, B.K.; PHILLIPS, S.R.; OLSON, K.R.; EBELHAR, S.A. Tillage effects on selected chemical properties of Grantsburg silt loam. Communications in Soil Science and Plant Analysis, v.25, p.225-246, 1994.

MARIA, I.C. de; CASTRO, O.M. de. Fósforo, potássio e matéria orgânica em um Latossolo Roxo, sob sistemas de manejo com milho e soja. Revista Brasileira de Ciência do Solo, v.17, p.471-477, 1993.

McBRIDE, M.C. Reactions controlling heavy metal solubility in soils. Advances in Soil Science, v.10, p.1-56, 1989

MORA, M.L.; BAEZA, G.; PIZARRO, C.; DEMANET, R. Effect of calcitic and dolomitic lime on physicochemical properties of a Chilean Andisol. Communications in Soil Science and Plant Analysis, v.30, p.427-439, 1999.

MOREIRA, S.G.; KIEHL, J.C.; PROCHNOW, L.I.; PAULETTI, V. Calagem em sistema de semeadura direta e efeitos sobre a acidez do solo, disponibilidade de nutrientes e produtividade de milho e soja. Revista Brasileira de Ciência do Solo, v.25, p.71-81, 2001

OADES, J.M. Soil organic matter and structural stability: mechanisms and implications for management. Plant and Soil, v.76, p.319-337, 1984.

OLIVEIRA, M.L.; GARCIA, R.V.; MELLO, J.W.V.; PRIMAVESI, O. Efeito do tipo de manejo sobre o caráter eletroquímico de um Latossolo VermelhoAmarelo do estado de São Paulo. (Compact disc). In: CONGRESO LATINO AMERICANO DE LA CIÊNCIA DEL SUELO, 24., Temuco, 1999.

PAIVA, P.L.R.; FURTINI NETO, A.E.; VALE, F.R.; FAQUIN, V. Efeito do manejo do solo sobre os teores de matéria orgânica, nitrogênio mineral, fósforo $e$ base trocáveis. Ciência e Agrotecnologia, v.21, v.35-43, 1997.

POTTKER, D.; BEN, J.R. Calagem para uma rotação de culturas no sistema de plantio direto. Revista Brasileira de Ciência do Solo, v.22, p.675684, 1998.

RAIJ, B. van; QUAGGIO, JA; CANTARELLA, H; FERREIRA, M.E ; LOPES, A.S.; BATAGLIA, O.C. Análise química do solo para fins de fertilidade. Campinas: Fundação Cargill, 1987. 170p.

RANST, E. van; SHAMSHUDDIN, J.; BAERT, G.; DZWOWA, P.K Charge characteristics in relation to free iron and organic matter of soils form Bambouto Mountains, Western Cameroon. European Journal of Soil Science, v.49, p.243-252, 1998.

SÁ, J.C.M. Calagem em solos sob plantio direto da Região dos Campos Gerais, Centro Sul do Paraná. In: SÁ, J.C.M. (Coord.) Curso sobre o manejo do solo no sistema de plantio direto. Castro: Fundação $A B C$, 1995. p.73-107.

SCHNITZER, M. Binding of humic substances by soil mineral colloids. In: HUANG, P.M.; SCHNITZER, M., (Ed.) Interactions of soil minerals with natural organics and microbes. Madison: SSSA, 1986. p.77-101.

SELLES, F.; KOCHANN, R.A.; DENARDIN, J.E.; ZENTNER, R.P. FAGANELLO, A. Distribution of phosphorus fractions in a Brazilian Oxisol under different tillage systems. Soil \& Tillage Research, v.44, v.23-34, 1997.

SIQUEIRA, C.; LEAL, J.R.; VELLOSO, A.C.X. Eletroquímica de solos tropicais de carga variável. II. Quantificação do efeito da matéria orgânica sobre o ponto de carga zero. Revista Brasileira de Ciência do Solo, v.14, p.1317, 1990.

$\overline{\text { Received May 6, }} 2002$ 